\title{
HARGA SAHAM SEBELUM DAN SESUDAH STOCK SPLIT
}

\author{
STOCK PRICE BEFORE AND AFTER STOCK SPLIT ANNOUNCEMENT
}

\author{
Junita Putri Rajana Harahap ${ }^{1}$, Murni Dahlena Nasution ${ }^{2}$ \\ Univesititas Muslim Nusantara Al Washliyah ${ }^{1,2}$ \\ ririeharahap87@gmail.com ${ }^{1}$
}

\begin{abstract}
The stock split causes the stock price to be cheaper so that it will attract potential investors to buy the stock. This research was conducted to determine when it is time for a company to do a stock split, information available on the capital market can be used by investors for consideration before investors make a decision to invest in shares. The study aims to determine the changes that occur in stock prices before and after the stock split policy by the company. The research method used in this research is event study research with a quantitative approach. This study examines how significant the stock price difference is after a stock split policy. The sample used in this study were all companies that carried out the 2016-2018 stock split policy. The results of research on companies that become samples have shown that the average stock price before the announcement of the stock split policy has no significant difference with the average stock price after the announcement of the stock split policy
\end{abstract}

Keywords : Stock Price, Stock Split

\begin{abstract}
ABSTRAK
Pemecahan saham mengakibatkan harga saham menjadi lebih murah sehingga akan menarik calon investor untuk membeli saham tersebut. Penelitian ini dilakukan untuk menentukan kapan waktunya perusahaan melakukan Stock split, informasi yang ada pada pasar modal dapat digunakan oleh investor untuk bahan pertimbangan sebelum investor mengambil keputusan untuk berinvestasi pada saham. Penelitian bertujuan untuk mengetahui perubahan yang terjadi pada harga saham sebelum dan sesudah dilakukannya kebijakan Stock split oleh perusahaan. Metode penelitian yang digunakan dalam penelitian ini adalah penelitian event study dengan pendekatan kuantitatif. Penelitian ini menguji seberapa signifikan perbedaan harga saham setelah dilakukannya kebijakan stock split. Sampel yang digunakan dalam penelitian ini adalah semua perusahaan yang melakukan kebijakan stock split periode 2016-2018. Hasil penelitian pada perusahaan yang menjadi sampel menghasilkan bahwa rata-rata harga saham sebelum pengumuman kebijakan stock split mempunyai perbedaan yang tidak signifikan dengan rata-rata harga saham sesudah pengumuman kebijakan stock split
\end{abstract}

Kata Kunci: Harga Saham, Stock Split 


\section{PENDAHULUAN}

Harga saham yang terlalu tinggi tidak mampu dijangkau oleh calon investor maka dilakukan pemecahan saham oleh perusahaan. Jika harga saham menjadi lebih murah maka ada kemungkinan akan menyebabkan transaksi terhadap saham tersebut meningkat sehingga harga saham sering berubah dan dapat memberikan peluang untuk memperoleh keuntungan.

Pemecahan

saham mengakibatkan harga saham menjadi lebih murah sehingga akan menarik calon investor untuk membeli saham tersebut. Alasan mengapa perusahaan melakukan pemecahan saham kemungkinan dikarenakan harga saham yang terlalu tinggi sehingga saham tersebut tidak likuid, jika saham tidak likuid maka transaksi perdagangan terhadap saham tersebut akan semakin sedikit. Sedikitnya transaksi perdagangan yang terjadi menyebabkan harga tidak bergerak fluktuatif, sehingga harapan untuk mendapatkan return juga akan semakin sedikit.

Meskipun secara teoretis pemecahan saham tidak memiliki nilai ekonomis tapi banyak peristiwa pemacahan saham di pasar modal menunjukan bahwa pemecahan saham merupakan peristiwa yang penting dalam praktek pasar modal sebab pemecahan saham menjadikan harga saham menjadi lebih murah diharapkan akan mampu menjaga tingkat perdagangan saham dalam rentang yang optimal dan menjadikan saham likuid. Harga saham yang murah akan menyebabkan investor membelinya sehingga akan meningkatkan volume perdagangan.

Pemecahan saham adalah suatu kebijakan yang ditempuh oleh manajemen perusahaan dengan cara menarik kembali saham yang beredar dan ditukar dengan saham yang nilai nominalnya lebih kecil atau menarik kembali saham yang beredar dan ditukar dengan saham yang nominalnya lebih besar. Pada dasarnya ada dua jenis pemecahan saham yang dapat dilakukan yaitu pemecahan naik (split up) dan pemecahan turun (split down) (Sadikin, 2016).

Pengumuman pemecahan saham memang tidak memiliki nilai ekonomis tetapi hal lain sering direaksi oleh pasar, karena pengumumanya merupakan upaya perusahaan untuk menarik perhatian investor yang memberikan sinyal bahwa perusahaan memiliki kondisi yang baik. Keputusan untuk melakukan pemecahan saham akan berpengaruh pada nilai perusahaan yang dicerminkan oleh harga saham perusahaan, akan tetapi tidak semua perusahaan mempunyai prospek bagus yang dapat menanggung biaya tersebut. Saham yang dianggap akan memberikan prospek untuk meraih keuntungan akan menarik investor dan salah satu cara yang dilakukan oleh perusahaan agar sahamnya kelihatan lebih menarik di mata investor adalah dengan cara pemechan saham

Pemecahan saham merupakan aksi emiten untuk melakukan pemecahan nilai nominal perlembar saham dan menambah jumlah lembar saham yang beredar sesuai dengan faktor pemecahanya (split factor) (Anwar \& Asindrimitra, 2018). Pemecahan saham ini tidak mempengaruhi modal yang disetor penuh, karena disini tidak terjadi penambahan modal di setor, tetapi hanyalah pemecahan nilai nominal yang lebih kecil sehingga jumlah lembar saham meningkat.

Harga saham berdasarkan fungsinya dapat dibagi menjadi tiga jenis yaitu : nilai nominal, harga dasar, dan harga pasar. Nilai nominal adalah nilai yang ditetapkan oleh emiten dan 
tercantum pada saham, besarnya nominal tergantung keinginan emiten yan bebas menetapkan harga per lembar sahamnya (Munthe, 2016).

Harga dasar muncul setelah saham aktif trading di padar sekunder, harga dasar saham bagi saham yang baru listing, berarti harga perdana saham bersangkutan. Harga pasar muncul dari tingkat penawaran dan permintaan suatu saham, harga pasar mencerminkan nilai saham emiten yang mengalami naik turun sesuai dengan likuiditas saham yang bersangkutan (Asriningsih, 2015).

Beberapa penelitian terdahulu telah juga meneliti harga saham sebelum dan sesudah stock split dan memperoleh hasil bahwa terdapat perbedaan harga saham sebelum dan sesudah stock split. Namun juga terdapat beberapa penelitian yang menunjukkan perbedaan hasil bahwa harga sahal sebelum maupun sesudah stock split adalah sama dan tidak terdapat perbedaan yang signifikan (Makhfidah \& Daniar, 2016; Firmansyah \& Agustin, 2016; Shofa \& Utiyati, 2016). Untuk itu, penelitian ini mencoba menggali kembali bagaimana harga saham sebelum dan sesudah stock split pada perusahaan yang melakukan stock split di BEI tahun 2016-2018:

\section{METODE PENELITIAN}

Pendekatan dalam penelitian ini adalah pendekatan kuantitatif. Populasi dalam penelitian ini adalah seluruh perusahaan yang terdaftar di BEI serta melakukan stock split periode tahun 2016-2018 serta saham-sahamnya masih aktif diperdagangkan di bursa teknik pengambilan sampel menggunakan teknik purposive sampling. Sampel yang digunakan sebanyak 10 perusahan dengan kriteria pengambilan sampel adalah :

1. Perusahaan mempublikasikan stock split di BEI pada tahun 2016-2018

2. Perusahaan yang data transaksi tersedia lengkap untuk kebutuhan analisis selama periode penelitian

3. Periode pengamatan 10 hari sebelum dan 10 hari sesudah stock split, dan tidak melakukan pembagian deviden, right issue, dan lain-lain

4. Perusahan yang melakukan ratio stock split 1:5

Adapun teknik analisa data yang digunakan dalam penelitian ini adalah analisis statistik deskriptif dan uji beda. Uji hipotesis ini menggunakan program SPSS dengan uji independent samples test.

HASIL DAN PEMBAHASAN Analisis Statistik Deskriptif

Tabel 1 Rata-Rata Harga Saham Sebelum dan Sesudah Stock split

\begin{tabular}{lllllll}
\hline No & Kode & Nama Emiten & Sebelum & Sesudah & $\begin{array}{l}\text { Ken/ } \\
\text { Pen }\end{array}$ & Ket \\
\hline 1 & ALKA & Alakasa Industrindo Tbk & 138 & 160 & 22 & Naik \\
\hline 2 & PSAB & J Resources Asia Pasifik Tbk & 305.37 & 346.57 & 41.2 & Naik \\
\hline 3 & KREN & Kresna Graha Investama Tbk & 441.25 & 414.28 & -26.97 & Turun \\
\hline 4 & ASMI & Asuransi Kresna Mitra Tbk & 417.75 & 436.57 & 18.82 & Naik \\
\hline 5 & MYRX & Hanson Internasional Tbk & 149.89 & 163.17 & 13.28 & Naik \\
\hline 6 & CLEO & Sariguna Primatirta Tbk & 255.5 & 242.66 & -12.84 & Turun \\
\hline
\end{tabular}




\begin{tabular}{lllllll}
\hline 7 & MINA & Sanurhasta Mitra Tbk & 407.42 & 547.12 & 139.7 & Naik \\
\hline 8 & TOPS & Totalindo Eka Persada Tbk & 858.66 & 915 & 56.34 & Naik \\
\hline 9 & GEMA & Gema Grahasarana Tbk & 269.5 & 302 & 32.5 & Naik \\
\hline 10 & KPIG & MNC Land Tbk & 136.5 & 133.77 & -2.73 & Turun \\
\hline
\end{tabular}

Sumber : Data Olahan 2020

Tabel diatas menjelaskan bahwa jumlah harga saham sebelum dan sesudah stock split sebesar 3379.84 dan 3661.14. Nilai rata-rata harga saham sebelum dan sesudah stock split adalah 337.98 dan 366.11. Saham mengalami

\section{Uji Beda Anova}

kenaikan sebesar $8.32 \%$ setelah pengumuman kebijakan stock split. 3 perusahaan mengalami penurunan harga saham setelah saham dipecah dan 7 perusahaan mengalami kenaikan harga saham setelah saham dipecah.

Tabel 2. Hasil Uji Independent Samples Test

\begin{tabular}{|c|c|c|c|c|c|c|c|c|c|c|}
\hline & & \multicolumn{5}{|c|}{ Levene's Test } & \multicolumn{4}{|c|}{ t-test for Equality of Means } \\
\hline & & \multirow[b]{2}{*}{ F } & \multirow[b]{2}{*}{ Sig. } & \multirow[b]{2}{*}{$\mathrm{T}$} & \multirow[b]{2}{*}{ df } & \multirow{2}{*}{$\begin{array}{l}\text { Sig. (2- } \\
\text { tailed) }\end{array}$} & \multirow{2}{*}{$\begin{array}{c}\text { Mean } \\
\text { Difference }\end{array}$} & \multirow{2}{*}{$\begin{array}{l}\text { Std. Error } \\
\text { Difference }\end{array}$} & \multicolumn{2}{|c|}{$\begin{array}{l}95 \% \text { Confidence Interval } \\
\text { of the Difference }\end{array}$} \\
\hline & & & & & & & & & Lower & Upper \\
\hline \multirow[t]{2}{*}{$\begin{array}{l}\text { Stock } \\
\text { split }\end{array}$} & $\begin{array}{l}\text { Equal } \\
\text { variances } \\
\text { assumed }\end{array}$ & .052 & .822 & -.278 & 18 & .784 & -28.13000 & 101.11528 & -240.56531 & 184.30531 \\
\hline & $\begin{array}{l}\text { Equal } \\
\text { variances } \\
\text { not } \\
\text { assumed }\end{array}$ & & & -.278 & $\begin{array}{r}17 . \\
874\end{array}$ & .784 & -28.13000 & 101.11528 & -240.67263 & 184.41263 \\
\hline
\end{tabular}

Sumber : Data Olahan 2020

Dari tabel 2 di atas dapat dilihat bahwa nilai signifikansi 2 tailed sebesar $0,784>0,05$ menunjukan bahwa tidak terdapat perbedaan yang signifikan harga saham sebelum dan sesudah stock split.

Hasil output SPSS terhadap hasil uji beda harga saham selama sepuluh hari sebelum dan sesudah stock split secara keseluruhan diketahui bahwa hasil pengujian terhadap rata-rata harga saham sebelum dan sesudah stock split diperoleh t hitung sebesar -0,278 dengan signifikasi sebesar 0,784 . Karena signifikasi lebih besar dari 0,05 maka dapat dikatakan Ho diterima dan Ha ditolak, artinya tidak terdapat perbedaan antara rata-rata harga saham sebelum dan sesudah stock split.

Hasil penelitian ini konsisten dengan penelitian Makhfidah \& Daniar (2016); Firmansyah \& Agustin (2016); Shofa \& Utiyati (2016) yang menyimpulkan bahwa pengumuman stock split tidak memberikan pengaruh positif terhadap harga saham sehingga tidak ada perbedaan yang signifikan antara harga saham sebelum dan sesudah stock split. Pengujian terhadap perusahaan sampel menghasilkan tidak adanya beda antara harga saham sebelum dan harga saham setelah stock split. 
Stock split diharapkan dapat menarik investor untuk membeli saham perusahaan yang akhirnya akan menaikkan jumlah transaksi terhadap saham yang bersangkutan. Naiknya jumlah transaksi terhadap saham yang diperdagangkan diharapkan dapat menaikkan harga saham. Selain itu, kemungkinan perusahaan melakukan stock split adalah menghindari kemungkinan delisting dari bursa karena rendahnya jumlah transaksi terhadap saham perusahaan. Dengan harga saham yang lebih rendah akan meningkatkan jumlah transaksi atas saham yang bersangkutan sehingga penjualan saham dibursa tetap berada pada batas yang ditentukan (Sadikin 2016).

\section{PENUTUP}

\section{Kesimpulan}

Berdasarkan hasil penelitian yang sudah di jelaskan di atas, dapat disimpulkan beberapa simpulan sebagai berikut :

1. Hasil pengujian hipotesis terhadap sampel penelitian menunjukkan bahwa rata-rata harga saham sebelum stock split tidak mengalami perbedaan signifikan dengan rata-rata harga teoritis saham sesudah stock split.

2. Rata-rata harga saham selama 10 hari sebelum dilakukannya kebijakan stock split sebesar 337.98 dan ratarata harga saham selama 10 hari sesudah dilakukannya kebijakan stock split sebesar 366.11

3. Saham mengalami kenaikan sebesar $8.32 \%$ setelah pengumuman kebijakan stock split.

\section{Saran}

Berdasarkan hasil penelitian para investor dan calon investor baiknya memperhatikan kebijakan yang dikeluarkan perusahaan atas pengumuman stock split untuk proses pengambilan keputusan investasi saham sehingga dapat mengurangi risiko dan memperhitungkan laba. Bagi perusahaan perlu mempertimbangkan faktor yang melatarbelakangi keputusan melakukan stock split seperti ketidakstabilan faktor internal yang berimbas pada sentimen pasar. Bahwa aktifitas stock split tidak serta merta mengakibatkan harga saham akan meningkat sesuati dengan tujuannya.

\section{DAFTAR PUSTAKA}

Asriningsih, W. (2015). Analisis Abnormal Return dan Likuiditas Saham Sebelum dan Sesudah Stock Split Periode 20082012. Jurnal Economia,11(1), 10-15.

Anwar, F., \& Asandimitra, N. (2018). Analisis Perbandingan Abnormal Return, Trading Volume Activity, dan Bid-Ask Spread Sebelum dan Sesudah Stock Split. BISMA (Bisnis dan Manajemen), 7(1), 34-44.

Firmansyah, A. D., \& Agustin, S. (2016). Analisis Perbandingan Trading Volume Activity Dan Abnormal Return Sebelum Sesudah Stock Split. Jurnal Ilmu dan Riset Manajemen (JIRM), 5(5).

Makhfidah, S., \& Daniar Paramita, R. W. (2016). Analisis Harga Saham dan Volume Perdagangan Saham sebelum dan sesudah stock split. Analisis Harga Saham dan Volume Perdagangan Saham sebelum dan sesudah stock split, 9(2), 97103. 
Munthe, K. (2016). Perbandingan Abnormal Return Dan Likuditas Saham Sebelum Dan Sedudah Stock Split: Studi Pada Perusahaan Yang Terdaftar Di Bursa Efek Indonesia. Jurnal Akuntansi, 20(2), 254-266.

Shofa, I., \& Utiyati, S. (2016). Analisis perbandingan harga dan volume perdagangansaham sebelum dan sesudah stock split. Journal ilmu dan riset manajemen, 5(7).

Sadikin, A. (2016). Analisis Abnormal Return Saham Dan Volume Perdagangan Saham, Sebelum Dan Sesudah Peristiwa Pemecahan Saham (Studi Pada Perusahaan Yang Go Publik Di Bursa Efek Indonesia. Jurnal manajemen dan akuntansi, 12(1). 